Neth. J. P1. Path. 79 (1973) 5-8

\title{
Systemic infection of tomato plants with tobacco mosaic virus following inoculation of seedling roots
}

\author{
A. TH. B. RAST* \\ Institute of Phytopathological Research (IPO), Wageningen
}

Accepted 21 June 1972

\begin{abstract}
In order to inoculate roots of tomato seedlings with tobacco mosaic virus, seeds were germinated singly in perforated plastic tubing obtained from ladies' hair curlers filled with sieved soil. The time which elapsed between inoculation of the roots and observation of first leaf symptoms varied with individual plants between one and ten weeks and was on average three to five weeks. As plant raising requires about six to eight weeks in winter, mosaic symptoms appearing in a tomato crop after planting out may well be the result of a root infection sustained during pricking off of the seedlings in the nursery.
\end{abstract}

\section{Introduction}

Fulton (1941), Roberts (1950) and Broadbent (1965a, b) showed that tomato plants can become infected with TMV through their roots. It was demonstrated that the upward movement of the virus in infected roots was much slower than its downward movement, probably because normally it is carried downward passively with the stream of assimilates. Like many soil-borne viruses (cf. Van Hoof, 1967) TMV was often found to be confined to the root system. Its entry into the stem and subsequent systemic infection of the aerial parts depended on season, age and susceptibility of the plant. Broadbent (1965a) found the time required for systemic infection varied between 3 weeks and 6 months with an average of 2 to 3 months. This applied to plants of different ages, which were not exposed to root infection before at least 5 to 7 true leaves had developed. Tomato seedlings, however, became systemically infected within 3 weeks following inoculation of the roots in summer and within 5 weeks in winter (Broadbent, 1965b). Van Winckel (1965) found the roots to be more often contaminated by the virus than the cotyledons, which suggests that the risks of root infection of seedlings are greater than infection of the cotyledons. For practical reasons it was important to know whether root infections occurring during pricking off seedlings in the nursery may be responsible for the appearance of mosaic symptoms soon after planting out.

\section{Methods}

Root inoculation of small batches of seedlings was carried out at monthly intervals in the winters of $1967 / 1968$ and $1968 / 1969$. To avoid contact with the cotyledons during

- Stationed at the Glasshouse Crops Research and Experiment Station, Naaldwijk, The Netherlands. 


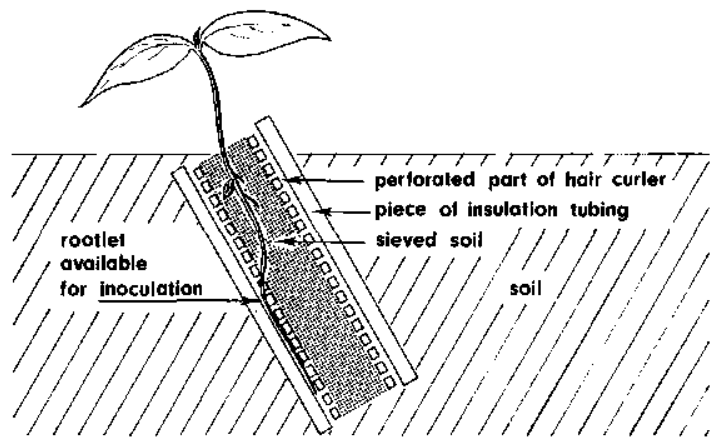

Fig. 1. Schematic representation of the method used for inoculation of seedling roots.

Fig. 1. Schematische weergave van de gebruikte methode om wortels van zaailingen te inoculeren.

inoculation, tomato seeds were germinated singly in sieved soil pressed gently into pieces of perforated plastic tubing, obtained from ladies' hair curlers. These were slid into a piece of plastic insulation tubing and the whole buried in soil at a slight angle (Fig.1). A few days after germination the curlers containing the seedlings with clean rootlets fit for inoculation, were carefully lifted from the enclosing plastic tube. The rootlets were inoculated with a paint brush dipped in highly infective leaf sap prepared by grinding $1 \mathrm{~g}$ of infected tomato leaves in about $20 \mathrm{ml}$ of tap water. The curlers with the seedlings were then transplanted into pots of $8 \mathrm{~cm}$ diameter. Subsequently the appearance of mosaic symptoms was recorded and at times both leaves and roots of plants not visibly infected, were separately assayed on Nicotiana glutinosa. As these

Table 1. Systemic infection of tomato plants with TMV following inoculation of seedling roots.

\begin{tabular}{|c|c|c|c|c|c|c|c|c|c|c|c|c|c|c|c|}
\hline \multirow[t]{3}{*}{ Sowing date } & & \multirow{3}{*}{$\begin{array}{l}\text { Inocu- } \\
\text { lation } \\
\text { date }\end{array}$} & \multirow{2}{*}{\multicolumn{10}{|c|}{$\begin{array}{l}\text { Num- Number of plants with first leaf } \\
\text { ber of symptoms in weeks following } \\
\text { plants } \\
\text { inoculation }\end{array}$}} & \multicolumn{3}{|c|}{ Number of plants } \\
\hline & & & & & & & & & & & & & \multirow{2}{*}{$\begin{array}{l}\text { not } \\
\text { infec- } \\
\text { ted }\end{array}$} & \multicolumn{2}{|c|}{ infected in } \\
\hline & & & ulated 1 & 2 & 3 & 4 & 5 & 6 & 7 & 8 & 9 & $\begin{array}{c}10 \\
\text { weeks }\end{array}$ & & $\begin{array}{l}\text { roots } \\
\text { only }\end{array}$ & $\begin{array}{c}\text { roots }+ \\
\text { leaves }\end{array}$ \\
\hline \multirow[t]{8}{*}{$1967 / 1968$} & $11 / 9$ & $21 / 9$ & 13 & & 5 & 1 & 1 & & 2 & & & & 4 & 0 & 9 \\
\hline & $9 / 10$ & $23 / 10$ & 14 & 2 & 2 & 3 & 1 & & & & 3 & & 3 & 0 & 11 \\
\hline & $9 / 11$ & $22 / 11$ & 11 & & & & 6 & & & & & & $5^{*}$ & - & 6 \\
\hline & $8 / 12$ & $22 / 12$ & 13 & & & & 1 & 3 & & & & & 9 & 0 & 4 \\
\hline & $10 / 1$ & $22 / 1$ & 15 & & 5 & 3 & 6 & & & & & & $1^{*}$ & - & 14 \\
\hline & $9 / 2$ & $21 / 2$ & 17 & 2 & 4 & 1 & 2 & 4 & & & & & 2 & 2 & 13 \\
\hline & $10 / 3$ & $21 / 3$ & 12 & & 5 & 3 & & & & & & & 4 & 0 & 8 \\
\hline & $10 / 4$ & $24 / 4$ & 9 & 5 & & & & & & & & & $4^{*}$ & - & 5 \\
\hline \multirow[t]{7}{*}{$1968 / 1969$} & $10 / 9$ & $24 / 9$ & 21 & & 3 & 4 & 5 & & 6 & & & & 1 & 2 & 18 \\
\hline & $9 / 10$ & $24 / 10$ & 25 & & & 2 & 5 & 2 & 7 & 3 & & & $6^{*}$ & - & 19 \\
\hline & $11 / 11$ & $25 / 11$ & 25 & & & 4 & 5 & 5 & 2 & 1 & 3 & 1 & 4 & 0 & 21 \\
\hline & $10 / 12$ & $24 / 12$ & 25 & 2 & 2 & 8 & 7 & & 1 & 1 & & & 6 & 0 & 19 \\
\hline & $10 / 1$ & $24 / 1$ & 16 & & & 3 & & & 2 & & & 6 & 1 & 4 & 11 \\
\hline & $10 / 2$ & $24 / 12$ & 16 & 1 & 4 & 1 & 3 & 1 & & & & & 3 & 3 & 10 \\
\hline & $11 / 3$ & $24 / 3$ & 16 & 1 & 6 & & 6 & & & & & & $3^{*}$ & - & 13 \\
\hline
\end{tabular}

* = plants not assayed, actual state of infection being unknown.

Tabel 1. Systemische infectie van tomateplanten met TMV na inoculatie van wortels van zaailing. 
plants had to remain alive, only pieces of the top leaves and of roots growing through the openings in the bottom of the pots were used for the assay.

\section{Results and discussion}

The results presented in Table 1 are incomplete because no assays were made in part of the experiments, the remainder of plants without leaf symptoms possibly being infected only in the roots. Nevertheless, the results show that only part of the plants became systemically infected by inoculation of seedling roots. The first leaf symptoms appeared towards the end of the 2nd week in five experiments (October 1967, February 1968, April 1968, February 1969, March 1969) but only in the 4th or 5th week in five other experiments (November 1967, December 1967, October 1968, November 1968, January 1969). This suggests seasonal effects. In spite of the highly infective inoculum used, systemic infection developed very slowly as is indicated by the experiment in January 1969 in which six plants started to show symptoms during the 10th week. In some cases the infection was confined to the roots. Under commercial conditions similarly infected plants remain undetected by the grower during the plant raising period, which may last from 6 to 8 weeks in winter. So it is possible that mosaic symptoms appearing shortly after planting out may still result from root infection during the seedling stage originating from infected seeds or contaminated seed coats.

\section{Samenratting}

Systemische infectie van tomateplanten met tabaksmozaïekvirus na inoculatie van wortels van zaailingen

Om bij kiemplanten van tomaat wortelinoculaties met TMV uit te voeren werden geperforeerde plastiek hulzen, afkomstig van haarkrullers, met aarde gevuld en gebruikt voor het afzonderlijk laten kiemen van tomatezaden. $\mathrm{Na}$ inoculatie van de wortels, welke door de perforatie van de huls waren heengegroeid (Fig. 1), werden de desbetreffende kiemplanten tegelijk met de huls in potten overgeplant. Vervolgens werd het verschijnen van bladsymptomen afgewacht, terwijl van tijd tot tijd van uiterlijk nietgeinfecteerde planten zowel bladeren als wortels afzonderlijk werden getoetst op Nicotiana glutinosa. Uit de resultaten (Tabel 1) is gebleken, dat een aantal planten niet of slechts in de wortels werd geïnfecteerd. Bij de meeste planten had inoculatie van de wortels een systemische infectie tot gevolg. De periode tussen wortelinoculatie en waarneming van de eerste bladsymptomen varieerde voor de individuele planten van één tot tien weken met een, ruw geschat, gemiddelde van drie tot vijf weken. Aangezien met de opkweek van planten in de winter zes tot acht weken gemoeid zijn, is het niet uitgesloten, dat het verschijnen van mozaïeksymptomen kort na het uitplanten nog het gevolg is van een wortelinfectie in het kiemplantstadium.

\section{References}

Broadbent, L., 1965a. The epidemiology of tomato mosaic. VIII. Virus infection through tomato roots. Ann. appl. Biol. 55: 57-66.

Broadbent, L., 1965b. The epidemiology of tomato mosaic. XI. Seed transmission of TMV. Ann. appl. Biol. 56: 177-205. 
Fulton, R. W., 1941. The behaviour of certain viruses in plant roots. Phytopathology 31: 575-598. Hoof, H. A. van, 1967. Aaltjes als virusoverbrengers bij planten. Landbouwk. Tijdschr. 79: 38-42. Roberts, F. M., 1950. The infection of plants by viruses through roots. Ann. app. Biol. 7: 385-396. Winckel, A. van, 1965. Tabakmozaïekvirus op tomatenzaad. Agricultura, Leuven 4, 721-729.

\section{Addresses}

Proefstation voor de Groenten- en Fruitteelt onder Glas, Zuidweg 38, Naaldwijk, the Netherlands. 